\title{
PEMAHAMAN IDENTITAS ETNIK (ETHNIC IDENTITY) UNTUK MENGEMBANGKAN TOLERANSI MASYARAKAT KOTA METRO LAMPUNG
}

\author{
Widodo \\ Program Studi S3 Ilmu Pendidikan, Universitas Negeri Yogyakarta \\ widodomankaur@gmail.com
}

\begin{abstract}
Abstrak
Keanekaragaman suku, bahasa, adat, dan agama merupakan keniscayaan sekaligus menjadi kekayaan bangsa Indonesia. Namun, dinamika interaksi sosial dalam masyarakat sering mengakibatkan terjadinya konflik antar etnis maupun antar agama karena kurangnya pengetahuan dan pemahaman terhadap Ethnic Identity (Identitas Etnik). Artikel ini bertujuan memotret keragaman masyarakat dan pemahaman identitas etnis dalam mengembangkan toleransi masyarakat Kota Metro, Lampung, menggunakan pendekatan kualitatif deskriptif. Data dikumpulkan melalui pengamatan langsung serta menelaah berbagai sumber dari media cetak maupun elektronik. Hasilnya menunjukkan bahwa; a) berdasarkan telaah berita pada media massa, tidak pernah terjadi konflik yang melibatkan suku dan agama di Kota Metro seperti yang terjadi di beberapa kabupaten lainnya di Provinsi Lampung, b) Adanya kerjasama antar pemerintah dan masyarakat untuk mewujudkan kerukunan hidup yang harmonis melalui kegiatan rutin seperti peringatan hari jadi Kota Metro dan upacara Pemilihan Bujan Gadis Lampung (Buyai Nuban) yang melibatkan seluruh elemen masyarakat tanpa membedakan latar belakang etnis yang bersangkutan.
\end{abstract}

Kata Kunci: Identitas Etnis, Toleransi, Keanekaragaman

\begin{abstract}
The diversity of ethnic, language, customs, and religion is a necessity as well as a wealth of the Indonesian nation. However, the dynamics of social interactions in the community often result in conflicts between ethnic and inter-denominations due to lack of knowledge and understanding of Ethnic Identity. This article aims to picture the community diversity and understanding of ethnic identity in developing community tolerance of Metro City, Lampung, using a descriptive qualitative approach. Data is collected through direct observation and review of various sources both printed or electronic media. The result show that: a) Based on the news on the mass media, there was never a conflict involving tribes and religions in Metro City as it happened in several other districts in Lampung Province, $b$ ) There is cooperation between the government and the community to create the harmony of living through routine activities such as commemoration of the Metro City anniversary and the election ceremony of Bujan Gadis Lampung (Buyai Nuban) involving all elements of society Without distinguishing the ethnic background in question.
\end{abstract}

Keywords: Ethnic Identity, Tolerance, Diversity 


\section{PENDAHULUAN}

Keragaman budaya belum dikelola menjadi asset budaya Indonesia. Secara historis dan sosiologis, keragaman suku, bahasa dan agama hampir merata diseluruh wilayah Indonesia merupaka kekayaan dan asset bangsa Indonesia. Realitas ini terjadi akibat hubungan historis, lingua franca dan jalur pelayaran tradisional sebagai kawasan nusantara. Proses percepatan keragaman dan kemajemukan secara massif di Indonesia diawali oleh Penjajahan Belanda masa melaksanakan program kolonilasisi. Banyak penduduk dari Jawa Tengah, Jawa Barat, Madura, Jawa Timur dan Bali mengikuti program tersebut.

Disitegrasi sosial di masyarakat menjadi fenomena sosial dalam kehidupan sosial. Oleh karena itu ancaman disintegrasi yang dihadapi bangsa Indonesia sangat dibutuhkan usaha nyata untuk menjaga dan merawat keberagaman. Keragaman merupakan keniscayaan dan harus memperkuat Bhineka Tunggal Ika. Memperkokoh rasa nasionalisme dan menjalin toleransi antar sesama akan terwujud jika masyarakat sadar dan mempunyai pemahaman akan ethnic identity dengan baik dan menyeluruh. Agar pemahaman identitas etnik dapat terlaksana dengan baik dan menyeluruh, Castellis dalam Buchari, 2014.23), menyatakan ada tiga pembentukan untuk membangun identitas, yakni; identitas legitimasi, identitas resisten dan identitas proyek.

Perkembangan peningkatan keragaman etnis pada suatu daerah dimulai sejak Indonesia merdeka melalui program transmigrasi besar-besaran bahkan sampai keseluruh pulau di luar Jawa.Salah satu daerah tujuan transmigrasi yang paling favorit dari zaman kolonialisasi sampai era transmigrasi zaman orde baru adalah provinsi Lampung yang secara letak paling dekat dengan Pulau Jawa. Oleh karena keragaman dan kemajemukan etnik semakain meningkat maka kegiatan interaksi diantara mereka semakin bervariasi, banyak yang positif ada juga yang berdampak negative. 
Oleh karena kurangnya pemahaman indentiats etnik dalam masyarakat kadang kala menimbulkan dinamika sosial berupa gesekan, pertikaian bahkan terjadi konflik. Berdasarkan laporan World Bank (2010) dalam Conflik and Development Program, menyebutkan mengenai dinamika konflik di enam provinsi yang terkena dampak dari konflik berskala besarAceh, Sulawesi Tengah, Maluku, Maluku Utara, Papua, dan Papua Baratselama periode 1998-2008. Hasilnya menunjukkan bahwa:

1. Meluasnya konflik komunal dan separatis yang mewarnai transisi demokrasi di Indonesia kini telah dapat dikatakan berakhir, setelah masa puncaknya 1999-2004. Meski demikian, berbagai faktor yang memicu dan mendorong beragam konflik tersebut belum sepenuhnya ditangani dan persoalan konflik lama kerap memicu insiden kekerasan yang baru.

2. Pada enam provinsi tersebut terdapat tingkat konflik kekerasan rutin yang tinggi-yang seringkali berupa bentrokan antar kelompok geng (preman), demonstrasi politik yang berujung ricuh, pengeroyokan terhadap pencuri, atau pertikaian masalah lahan. Dari bentuk-bentuk konflik kekerasan tersebut, sejak 2006 terjadi rata-rata 2.000 insiden konflik kekerasan per tahun pada enam provinsi yang dihuni hanya 4 persen dari penduduk Indonesia. Selama 2006-2008, konflik tersebut telah menelan korban tewas lebih dari 600 orang, 6.000 korban luka-luka, dan lebih dari 1.900 bangunan hancur. Mengingat meluasnya kekerasan berskala besar pada masa lalu diawali oleh insiden kekerasan berskala kecil, tingginya tingkat kekerasan rutin menandai potensi eskalasi konflik.

3. Sifat konflik kekerasan di Indonesia telah mengalami perubahan secara gradual. Bila pada periode 1999-2004, isu-isu identitas melatarbelakangi kebanyakan kasus kekerasan berskala besar, kini isu moral/tersinggung yang kian mengemuka, dan menyebabkan lebih dari setengah jumlah korban tewas akibat konflik pada beberapa tahun terakhir. Bentuk dari insiden kekerasan yang marak terjadi pun berubah. Meski kerusuhan dan bentrokan antarkelompok masih terjadi, frekuensinya telah berkurang, dan insiden penganiayaan dan perkelahian yang paling banyak menyebabkan korban tewas pada beberapa tahun terakhir. 
4. Respon aparat keamanan terhadap konflik kekerasan masih lemah. Hanya 7 (tujuh) persen konflik kekerasan yang terdata dalam database selama 2005-2008 ditangani secara langsung oleh pihak militer atau kepolisian, termasuk Brimob. Konflik antar unsur atau elemen dalam tubuh militer atau kepolisian, yang sempat menghambat efektivitas penegakan hokum selama periode konflik berskala tinggi, terus terjadi dan menyebabkan insiden yang mematikan.

Di antara keenam provinsi tersebut di atas, Papua merupakan provinsi dengan tingkat jumlah insiden kekerasan tertinggi dan Provinsi Maluku tercatat mengalami kenaikan yang paling tajam dalam jumlah insiden kekerasan pada beberapa tahun terakhir. Di Provinsi Aceh, kekerasan separatis berakhir pada 2005, namun sebaliknya jumlah insiden terkait isu moral/tersinggung justru meningkat sejak saat itu dan kekerasan pasca perjanjian damai (penandatanganan $\mathrm{MoU}$ ) terkonsentrasi pada wilayah yang merupakan pusat kekerasan sebelum MoU juga. (Conflict and Development Program; 2010).

Laporan tersebut menunjukan bahwa, tingkat, bentuk dan dampak konflik kekerasan sangat bervariasi antar kabupaten. Peristiwa konflik di atas memperlihatkan betapa signifikannya factor lokal dalam mendorong terjadinya insiden kekerasan. Dapat dikatakan keaneragaman etnis atau suku bangsa menjadi kekayaan bangsa apabila pengelolaan tepat dan menyeluruh sekaligus dapat menjadi pemicu penyebab terjadinya konfik yang besar dan banya memaka korban baik harta dan nyawa.

Thahir (2006: 10) menyatakan bahwa penyebab terjadinya konflik di suatu daerah dikarenakan oleh politisasi identitas budaya, sentimen agama, dan sumber daya ekonomi untuk kepentingan kelompok atau individu yang menjadikan agama dan budaya sebagai legitimasi untuk merebut pengaruh, kekuasaan, serta penguasaan terhadap sumber-sumber ekonomi.

Dilematis pada realitas kehidupan masyarakat tergambarkan pada keinginan agama dan budaya mewujudkan hak-haknya dalam realitas 
kehidupan berbangsa dan bernegara dalam skala lokal, sedangkan di satu sisi negara menuntut lebih besar pelaksanaan kewajiban politiknya, ketika negara tidak lagi menjadi sasaran konflik, konflik cenderung mengarah pada pertentangan antar budaya (etnik) atau antar umat beragama di mana masingmasing pihak yang bertikai hendak mengimplementasikan hak-haknya Kondisi ini semakin parah ketika isu-isu mengenai kesenjangan sosial ekonomi mewarnai wacana kebangsaan dan kenegaraan, terutama ketika kaum pendatang menguasai sentra-sentra ekonomi (Thahir, 2006: 10).

Berdasarkan kajian historis keragaman masyarakat lampung, Saroso (2014) menyebutkan bahwa program kolonisasi yang dilakukan oleh pemerintah kolonial mengakibatkan masuknya berbagai suku yang ada di pulau Jawa untuk pindah ke seluruh provinsi di Indonesia termasuk di Lampung. Hal itu berawal pada tahun 1901 ketika pemerintah Belanda memindahkan 155 kepala keluarga dari Desa Bagelen, Purworejo, Jawa Tengah ke sebuah hutan belantara di Lampung melalui program perluasan areal pertanian (kolonisasi). Orang-orang dari Pulau Jawa diangkut ke Lampung untuk membuka areal pertanian untuk kepentingan Belanda.

Program yang merupakan bagian dari politik balas budi Belanda itu, sebenarnya diarahkan untuk mendukung upaya Belanda mengelola tanah perkebunan di Lampung.Bukan hanya orang-orang Bagelen dipindahkan ke Lampung, tetapi juga orang-orang dari berbagai daerah lain di Jawa Tengah, Yogyakarta, Jawa Timur, Jawa Barat, dan Bali. Kemudian, pada periode tahun 1950-1969 perpindahan penduduk ke Lampung kembali terjadi kali ini jumlahnya mencapai 53.263 keluarga atau sebanyak 221.035 jiwa.Memasuki era Pembangunan Lima Tahun (Pelita), Lampung mendapat lagi tambahan penduduk sebanyak 22.362 kepala keluarga asal Jawa, Madura, dan Bali.Semakin banyaknya perpindahan penduduk itu berdampak pada terjadinya ledakan penduduk. Kalau pada tahun 1905 penduduk Lampung kurang dari 150 ribu dan didominasi suku asli Lampung, suku Jawa di $\begin{array}{llll}\text { Lampung mencapai } & \text { sekitar } & 60 & \text { persen }\end{array}$ 
(http://www.teraslampung.com/2014/02/sejarah-kolonisas-di-lampungimereka).

Keanekaragaman suku etnis di suatu daerah sering terjadi suasana kurang kondusif ketika isu-isu mengenai kesenjangan sosial ekonomi mewarnai wacana kebangsaan dan kenegaraan, terutama ketika kaum pendatang menguasai sentra-sentra ekonomi. Biasanya sebagai warga pendatang mempunyai etos dan semangat kerja yang tinggi menbawa tingkat perekonomian warga pendatang lebih mapan. Penguasaan akses ekonomi dari salah satu kelompok atau komunitas etnik dikuasai kelompok pendatang berdampak pada munculnya kecemburuan sosial ekonomi dari pihak pribumi.

Realitas keragaman masyarakat kota Metro pada dasarnya sama jika dibandingkan dengan beberapa kabupaten lainnya di Provinsi Lampung. Pertikaian berskala besar antar etnis akibat interaksi soaial dikarenakan hembusan isu ego-etnis dan kesejangan sosial ekonomi tidak terjadi di Kota Metro. Walaupun keanekaragaman suku, agama, adat dan budaya Kota Metro sama dengan kabupaten yang lain Lampung. Keharmonisan kehidupan dan interaksi warga kota Metro lebih menunjukan stabilitas keamanan, solidartitas serta toleransi terjaga dengan baik walaupun mejadi kota terbesar kedua di Provinsi Lampung. Jika dilihat dari tingkat keragaman kota Metro lebih hiterogen, sebagai kota pendidikannya menjadi daya tarik pemuda dan orang tua untuk bersekolah menuntut ilmu. Sebagai kota besar kedua Provinsi Lampung tentunya proses interaksi antar warga lebih konpleks, beragam dan sering bersentuhan dengan warga luar atau pendatang lainya.

Perkembangan pembangunan yang diupayakan oleh pemerintah, swasta dan masyarakat di Kota Metro mempunyai dampak yang luas dan mencakup berbagai dimensi kehidupan perkotaan.Peningkatan jumlah penduduk dan peningkatan kegiatan-kegiatan fungsional perkotaan mengakibatkan peningkatan kebutuhan masyarakat terhadap perumahan, sarana prasarana, dan fasilitas-fasilitas pelayanan kebutuhan hidup lainnya. Berkenaan dengan hal tersebut, diperlukan suatu perencanaan kota yang 
terpadu dan terarah agar sumber daya yang terbatas dapat dimanfaatkan secara efektif dan efesien.

Berbagai peristiwa konflik menjadi ujian bagi keutuhan Negara Kesatuan Republik Indonesia. Dampak kerugian dari peristiwa konflik sangat besar jika dilihat dari kemanusian, sosial dan ekonomi. Peristiwa konflik dapat menimbulkan disintegrasi bangsa Indonesia yang ber-Bhineka Tunggal Ika. Segala komponen baik pemerintah, keluarga dan masyarakat harus secara bersama-sama mencegah terjadinya peristiwa konflik di berbagai daerah, yang bersumber dari agama, suku, poltik atau hukum. Dibutuhkan pemahaman etnic identity agar terwujud toleransi di masyarakat sehingga stabilitas perstuan dan kesatuan Nasional Indonesia selalu terjaga.

Berdasarkan latar belakang masalah di atas dan kajian pada makalah ini tidak terlalu luas, maka rumusan masalah yang diajukan; pertama, bagaimanakah realitas keragaman etnis, agama, adat dan budaya yang terdapat di kota Metro Lampung, kedua, bagaimanakah pemahaman Ethnic Identity (Identitas Etnik) untuk Mewujudkan Toleransi pada Masyarakat di Kota Metro Lampung?

Agar penulisan artikel ini lebih terarah maka peneliti menggunakan metode penelitian deskriptif kualitatif seperti yang dikemukakan oleh Satori (2011: 23) menyatakan bahwa penelitian kualitatif dilakukan karena peneliti ingin mengeksplor fenomena-fenomena yang tidak dapat dikuantifikasikan yang bersifat deskriptif seperti proses suatu langkah kerja, formula suatu resep, pengertian-pengertian tentang suatu konsep yang beragam, karakteristik suatu barang dan jasa, gambargambar, gaya-gaya, tata cara suatu budaya, model fisik suatu artifak dan lain sebagainya. Pada tulisan ini peneliti menggunakan metode penelitian deskriptif kualitatif dikarenakan penulisan mengeksplor pemahaman identitas etnik untuk membangun toleransi pada masyarakat di Kota Metro Lampung. 


\section{PEMBAHASAN}

\section{Karakteristik Masyarakat Kota Metro Lampung}

Karakteristik masyarakat Kota Metro Lampung beraneka ragam baik suku bangsa, agama dan adat. Setiap suku mempunyai masing masing adat istiadat sendiri-sendiri. Secara khusus untuk warga Lampung dapat digolongkan dalam dua kelompok yaitu kelompok penduduk asli (suku Lampung) dan kelompok penduduk pandatang (dari luar daerah Lampung). Selanjutnya kelompok masyarakat adat suku asli memiliki struktur hukum adat tersendiri. Hukum tersebut berbeda antara yang satu dengan yang lainnya.Kelompok-kelompok tersebut menyebar di berbagai tempat, yang secara umum dapat dibedakan dalam dua kelompok besar yaitu masyarakat Lampung yang marga-marga beradat Pemingir/Saibatin (non-pepadun) dan marga-marga yang beradat Pepadun.

Penduduk Kota Metro secara umum dapat dikelompokan menjadi dua yaitu penduduk Pribumi (lampung Pepadun) dan penduduk pendatang (suku lain). Proses kedatangan suku Jawa, Bali serta Sunda merupakan program kolonsasi sebelum kemerdekaan Republik Indonesia dilanjutkan dengan program Transmigrasi setelah Indonesia Merdeka. Selanjutnya warga lain merupakan warga baru yang menetap dan tinggal di kota Metro merupakan pendatang yang berusaha, bekerja atau sekolah merasa nyaman betah menetap menjadi penduduk Kota Metro Lampung.

\section{Ethnic Identity}

\section{a. Pengertian Identitas Etnik (Ethnic Identity)}

Pinney (1992) menyatakan bahwa pengertian identitas etnik sebagai "suatu konstrak yang kompleks yang mencakup komitmen dan perasaan kebersamaan pada suatu kelompok, evaluasi positif tentang kelompoknya, adanya minat dan pengetahuan tentang kelompok, serta keterlibatan dalam aktivitas sosial dari kelompok" (Phinney, 1992). Dalam perkembangannya masalah identitas etnik, Phinney dan Rosenthal (1992) berpendapat dan menunjukkan bahwa tahap 
perkembangan identitas etnik bagi remaja sesuai dan sebanding dengan identitas Ego seperti yang dikemukan oleh Marcia.

Phinney (1989) menyebutkan tiga tahap perkembangan identitas etnik yang akan dilalui oleh individu sepanjang hidup yang dilalui dengan jalan proses eksplorasi dan komitmen. Tiga tahapan menurut Marcia dalam Phinney (1989) adalah :

1. Identitas Etnik "Unexamined", yang disebut Diffussion dan Foreclosure. Mengenai identitas etnik diffuse dan foreclosure tidak reliabel untuk dibedakan dan dikombinasikan ke dalam katagori yang dikarakteristikan dengan adanya hambatan minat atau tentang pengetahuan etnisitasnya sendiri atau latar belakang ras-nya. Ciri yang menentukan adalah tidak adanya eksplorasi. Individu dalam tahap ini belum berbuat banyak untuk belajar tentang kebudayaannya. Yang bersangkutan belum banyak membicarakannya dengan orang tua atau teman-teman mereka, belum mencari keterangan, melalui bacaan, kunjungan ke musium, dan sebagainya, sedangkan membaca buku-buku yang wajib sekolah tidak menunjukkan eksplorasi.

2. Identitas Etnic Search atau disebut Moratorium. menunjukkan tingginya ekplorasi akan keterlibatan atau mulai menjalin keterkaitan dengan etnisitasnya sendiri tanpa menunjukkan ada usaha ke arah komitmen. Ciri yang menentukan ialah keterlibatan aktif pada saat ini dalam proses eksplorasi, yaitu berusaha belajar lebih banyak tentang kebudayaan mereka, memahami latar belakang mereka, dan memecahkan persoalan yang berkaitan dengan arti dan implikasi keanggotaan mereka dalam kelompok etnis mereka, tetapi belum sampai pada komitmen yang jelas.

3. Identitas etnic achieved, dapat didefinisikan Sebagai adanya komitmen akan penghayatan kebersamaan dengan kelompoknya sendiri, berdasarkan pada pengetahuan dan pengertian atau mengerti akan perolehan atau keberhasilan melalui suatu eksplorasi 
aktif tentang latar belakang kulturnya sendiri. Ciri yang menentukan adalah remaja yang telah mencapai identitas etnik ialah perasaan aman dengan diri sendiri sebagai anggota kelompok etnik, termasuk penerimaan dan pemahaman implikasi sebagai anggota kelompok tersebut. Penerimaan ini didasarkan atas penanggulangan ketidakpastian tentang persoalan etnik sebagai hasil proses Eksplorasi. Eksplorasi mungkin terus berlanjut sementara mereka mencari pemahaman yang lebih mendalam.

Sejalan dengan pendapat di atas, Bank's yang menyebutkan bahwa kelompok etnis terdiri dari kelompok budaya dengan beberapa karakteristik yang membedakan. Selanjutnya kita dapat mendefinisikan kelompok etnis, namun, sebagai kelompok yang berbagi nenek moyang, budaya, sejarah, tradisi, rasa manusia, dan membentuk kelompok kepentingan politik dan ekonomi. Etnis kelompok juga merupakan kelompok yang tidak disengaja, meskipun identifikasi individu dengan kelompok mungkin bersifat opsional.

Berdasarkan definisi tersebut Bank's menunjukkan bahwa kelompok seperti Polandia-Amerika, Irlandia Amerika, dan AngloAmerika adalah kelompok etnis.Afro-Amerika dan Meksiko-Amerika adalah etnis kelompok minoritas, jenis kelompok etnis tertentu. Anggota kelompok etnis minoritas memiliki karakteristik fisik atau budaya unik yang memungkinkan anggota kelompok lain dengan mudah mengidentifikasi anggotanya, biasanya untuk tujuan diskriminasi.

\section{b. Identitas Sosial}

Identitas sosial merupakan hal yang pasti dimiliki oleh seseorang sejak Ia lahir hingga Ia meninggal. Identitas sosial Negara Asia, seperti China dan Indonesia sangat ditentukan oleh identitas individual atau personal.Hubungan antara indentitas personal dengan identitas sosial sangat dekat, dalam artian identitas personal dapat 
menembus identitas sosial kelompok. Pengaruh kekuasaan dalam pola budaya asia sangat tinggi atau high power distance sehingga pengaruh kelompok terhadap individu sangat kuat. Bila kondisi kelompok tersebut mengalami suatu ketidakadilan maka rasa senasib dan sepenanggungan mengalahkan segalanya.

Eksistensi identitas sosial akan tereduksi jika terjadi stereotype yang merupakan pengelompokan bentuk kompleks dari pengelompokan yang secara mental mengatur pengalaman seseorang dan arahkan ke orang-orang dalam berhubungan dengan orang tertentu keinginan yang berkuasa atau akibat pengaruh dari kekuasaan (Turner, 2008: 159). Gudykunst menyimpulkan seperti budaya dengan pengaruh kekuatan yang tinggi kompilasi "Individu dari budaya dengan pengaruh kekuatan yang tinggi menerima kekuatan sebagai bagian dari masyarakat. Jadi, penguasa menganggap bawahannya berbeda dari dirinya dan sebaliknya (Samovar, 2010: 188).

\section{Konsep Toleransi}

\section{a. Pengertian Toleransi}

Pengertian toleransi secara Bahasa berasal dari Bahasa
Inggris "Tolerance" yang berarti membiarkan. Dalam Bahasa
Indonesia diartikan sebagai sifat atau sikap toleran, mendiamkan,
membiarkan (KBBI, 1989: 955). Dalam Bahasa Arab kata toleransi
(mengutip kamus Al-munawir disebut dengan istilah tasamuh
yang berarti sikap membiarkan atau lapang dada) Badawi
mengatakan, tasamuh (toleransi) adalah pendirian atau
sikap yang termanifestasikan pada kesediaan untuk menerima
berbagai pandangan dan pendirian yang beraneka ragam
meskipun tidak sependapat dengannya (Bahari, 2010:51).
Sedangkan menurut Tillman toleransi adalah saling
menghargai, melalui pengertian dengan tujuan kedamaian.
Toleransi adalah metode menu ju kedamaian. Toleransi disebut


sebagai faktor esensi untuk perdamaian (Tillman, 2004:95), pada intinya toleransi berarti sifat dan sikap menghargai. Sifat dan sikap menghargai harus ditunjukkan oleh siapapun terhadap bentuk pluralitas yang ada di Indonesia. Sebab toleransi merupakan sikap yang paling sederhana, akan tetapi mempunyai dampak yang positif bagi integritas bangsa pada umumnya dan kerukunan bermasyarakat pada khususnya. Tidak adanya sikap toleransi dapat memicu konflik yang tidak diharapkan. Pelaksanaan sikap toleransi ini harus didasari dengan sikap kelapangan dada terhadap orang lain dengan memperhatikan prinsip-prinsip yang dipegang sendiri, yakni tanpa mengorbankan prinsip-prinsip tersebut (Ali, 1989:83).

Jelas bahwa toleransi terjadi dan berlaku karena terdapat perbedaan prinsip, dan menghormati perbedaan atau prinsip orang lain tanpa mengorbankan prinsip sendiri. Dalam memaknai toleransi ini terdapat dua penafsiran tentang konsep tersebut. Pertama, penafsiran negatif yang menyatakan bahwa toleransi itu cukup mensyaratkan adanya sikap membiarkan dan tidak menyakiti orang atau kelompok lain baik yang berbeda maupun sama.

\section{b. Pentingnya Sikap Toleransi dalam Masyarakat}

Proses interaksi sosial sering mengalami dinamika kadang harmonis baik dan terkadang terjadi gesekan. Untuk menjaga agar hubungan antar masyarakat selalu harmonis maka toleransi dapat menjadi kuncinya. Pentingnya sikap toleransi menurut Abdullah (2001: 13) menyebutkan bahwa toleransi mempunyai dua penafsiran yakni penafsiran positif yaitu menyatakan bahwa toleransi tidak hanya sekedar seperti pertama (penafsiran negatif) tetapi harus adanya bantuan dan dukungan terhadap keberadaan orang lain atau kelompok lain. 
Hubungan kenyamanan, kedamaian dan keharmonisan dalam bermasyarakat sangat erat kaitanya dengan toleransi. Tillman (2004) mengatakan dalam toleransi terdapat butir-butir refleksi, yaitu:

1) Kedamaian adalah tujuan, toleransi adalah metodenya. Toleransi adalah terbuka dan reseptif pada indahnya perbedaan.

2) Toleransi menghargai individu dan perbedaannya, menghapus topeng dan ketegangan yang disebabkan oleh ketidakpedulian. Menyediakan kesempatan untuk menemukan dan menghapus stigma yang disebabkan oleh kebangsaan, agama, dan apa yang diwariskan.

3) Toleransi adalah saling menghargai satu sama lain melalui pengertian.

4) Benih dari intoleransi adalah ketakutan dan ketidakpedulian. Benih dari toleransi adalah cinta, disiram dengan kasih dan pemeliharaan.

5) Jika tidak cinta tidak ada toleransi yang tahu menghargai kebaikan dalam diri orang lain dan situasi memiliki toleransi.

6) Toleransi juga berarti kemampuan menghadapi situasi sulit. Toleransi terhadap ketidaknyamanan hidup dengan membiarkan berlalu, ringan, membiarkan orang lain ringan.

7) Melalui pengertian dan keterbukaan pikiran orang yang toleran memperlakukan orang lain secara berbeda, dan menunjukkan toleransinya. Akhirnya, hubungan yang berkembang (Tillman, 2004.94).

Dapat disimpulkan, bahwa toleransi ialah sikap seseorang dimana mampu membiarkan dengan lapang dada, menghargai, mengakui, menghormati, tidak dendam, pengertian, terbuka terhadap pendapat, perbedaan, pandangan, kepercayaan, kebiasaan, sikap dan sebagainya yang lain atau yang bertentangan dengan pendiriann ya sendiri. Dalam toleransi terdapat 
unsur-unsur yang harus ditekankan dalam mengekspresikan terhadap orang lain. unsur-unsur tersebut adalah :

1) Memberikan Kebebasan dan Kemerdekaan, setiap manusia diberikan kebebasan untuk berbuat, bergerak maupun berkehendak menurut dirinya sendiri sendiri dan juga di dalam memilih satu agama atau kepercayaan. Kebebasan ini diberikan sejak manusia lahir sampai nanti ia meninggal dan kebebasan atau kemerdekaan yang manusia miliki tidak dapat digantikan atau direbut oleh orang lain dengan cara apapun, karena kebebasan itu adalah datangnya dari Tuhan YME yang harus dijaga dan dilindungi. Di setiap Negara melindungi kebebasan -kebebasan setiap manusia baik dalam UndangUndang maupun dalam peraturan yang ada (Abdullah, 2001:202).

2) Mengakui Hak Setiap Orang, suatu sikap mental yang mengakui hak setiap orang di dalam menentukan sikap perilaku dan nasibnya masing-masing. Tentu saja sikap atau perilaku yang di jalankan itu tidak melanggar hak oranglain karena kalau demikian, kehidupan di dalam masyarakat akan kacau.

3) Menghormati Keyakinan Orang Lain, konteks ini, diberlakukan bagi toleransi antar agama. Namun apabila dikaitkan dalam toleransi sosial. Maka menjadi menghormati keyakinan orang lain dalam memilih suatu kelompok.

4) Saling Mengerti, tidak akan terjadi, saling menghormati antara sesama manusia bila mereka tidak ada saling mengerti. Saling anti dan saling membenci, saling berebut pengaruh adalah salah satu akibat dari tidak adanya saling mengerti dan saling menghargai Antara satu dengan yang lain (Hasyim, 1979: 23).

\section{Upaya Pemahaman Identitas Etnik untuk Mengembangkan Toleransi}

\section{Masyarakat}

\section{a. Pemahaman Identitas Etnik melalui Pendidikan}


Membicarakan identitas etnik maka tidak dapat dipisahkan dengan modal sosial yang dimiliki oleh setiap etnis. Fukuyama (1995), mengartikan bahwa modal sosial, sebagai seperangkat nilai atau norma informal yang dimiliki bersama oleh anggota suatu kelompok yang memungkinkan kerja sama di antara mereka (Fukuyama, 1995: 19).

Selanjutnya menurut Putnam yang merupakan salah seorang ahli yang mempopulerkan konsep modal sosial. Menjelaskan, modal sosial merupakan bagian-bagian dari organisasi sosial seperti kepercayaan, norma dan jaringan, yang dapat meningkatkan efisiensi masyarakat dengan memfasilitasi tindakan-tindakan terkoordinasi (Lawang, 2004: 34). Dengan adanya kepercayaan, masyarakat akan mudah merancang suatu jaringan sosial atas prinsip kesukarelaan (voluntary), kesamaan (equality), kebebasan (freedom) dan keadaban (civility). Unsur berikutnya adalah norma, yakni sekumpulan aturan yang harus dipatuhi oleh masyarakat yang terlibat dalam jaringan sosial (Hasbullah, 2006: 8).

Berdasarkan analisis di atas posisi pendidikan sebagai salah satu institusi yang dapat memanfaatkan sebagai tempat pelembagaan studi agama berbasis pendidikan multikultural. Dalam insititusi pendidikan, diharapkan bisa dihindari adanya silang sengkarut agama di ranah sosial, karena ketidakmampuan dalam mengelola relasi agama pada wilayah pribadi dengan wilayah sosial agama. Salah satu institusi sosial penting dan strategis guna menanamkan konstruks yang lebih bersimpati dan berempati terhadap keberadaan agama lain dan pemahaman identitas etnis adalah pendidikan.

\section{b. Pendidikan Toleransi}

Mengingat pentingnya nilai toleransi, hal ini harus diterapkan dalam kehidupan sehari-hari. Upaya ini dilakukan guna menghindari konflik-konflik yang terjadi akibat tidak adanya rasa menghormati dan menghargai orang lain, seperti yang diungkapkan 
oleh Tilaar (1999:160) bahwa yang diperlukan dalam masyarakat bukan sekedar mencari kesamaan dan kesepakatan yang tidak mudah untuk dicapai, justru paling penting di dalam masyarakat yang ber-bhineka tunggal ika adalah adanya saling pengertian, tengang rasa dan saling menghargai.

Selanjutnya Hari cahyono (1995:203) mengatakan tujuan pengembangan sikap toleransi di kalangan siswa di sekolah maupun kelompok sosial, disamping sebagai wahana latihan agar mereka lebih lanjut dapat menerapkan dan mengembangkankannya secara luas dalam kehidupan masyarakat. Pendidikan toleransi dapat dilakukan dalam beberapa pendekatan, yaitu perorangan ( personal approach), pendekatan kelompok (interpersonal approach) dan pendekatan klasikal (classical approach) metode penyajiannya pun sangat beragam dan luwes melalui cerita, ceramah, permainan simulasi, tanya jawab, diskusi dan tugas mandiri. Singkatnya setiap bentuk sambung rasa (komunikasi) dapat dimanfaatkan dalam proses pendidikan (Sumaatmadja, N, 1990:9)

Untuk mengembangkan toleransi dapat dilakukan di sekolah atau pada masyarakat luas. Dapat dikatakan apabila anak didik terbiasa dengan toleransi di lingkungan sekolah dapat diterapkan di masyarakat.segala bentuk sambung rasa (komunikas) dapat digunakan untuk mengembangkan toleransi melalui tiga pendekatan yakni pendekatan perorangan (personal approach), pendekatan kelompok (Interpersonal Approach) dan pendekatan klasikal (Clasical Approach).Pendidikan toleransi dapat dilakukan oleh sekolah, keluarga dan masyarakat ketika masih terjadi sambung rasa.

\section{c. Pentingnya Pemahaman Ethnic Identity untuk Mengembangkan Toleransi}

Berdasarkan kajian Studi Konflik Kekerasan di Indonesia (VICIS) menujukkan realitas dan pengakuan yang kian menguat pada 
pemerintah dan masyarakat madani tentang perlunya sebuah perubahan pendekatan nasional terhadap pengelolaan konflik, dari pola penanganan yang bersifat sementara (adhoc) menjadi pengembangan sebuah kerangka kebijakan yang terpadu dan komprehensif dan mengadopsi pendekatan preventif. Beberapa inisiatif sudah mulai dilakukan untuk menyusun sebuah kerangka kebijakan tersebut, yang mencakup penyusunan draf Strategi Besar Pencegahan dan Pengelolaan Konflik (Grand Strategy for Conflict Prevention and Management) dan rancangan UU Pengelolaan Konflik Sosial. Temuan-temuan ViCIS memberikan penegasan bahwa inisiatif dimaksud seyogyanya mempertimbangkan isu dan upaya kunci berikut ini:

1) Pengembangan kerangka kebijakan yang komprehensif yang mengerucut pada faktor penyebab struktural dari konflik berskala besar pada masa lalu dan mengutamakan pengelolaan konflik kekerasan rutin untuk mencegah eskalasi konflik yang lebih luas.

2) Investasi pada kegiatan pemantauan konflik secara sistematis, khususnya di wilayah 'panas' (hotspot), sebagai instrument pendukung sistem peringatan dini.

3) Upaya-upaya peningkatan kemampuan para penegak hukum agar efektif menanggulangi dan menangani kekerasan. Penguatan mekanisme lokal dalam menyelesaikan sengketa untuk meningkatkan kohesi sosial masyarakat dan mencegah eskalasi konflik.

4) Investasi terus-menerus pada program pembangunan perdamaian (peace-building) di wilayah pascakonflik, dengan mengedepankan kepemimpinan lokal.

Lebih lanjut, Stella Ting dan Toomey (2008: 159), menyatakan, bahwa Partisipasi dan keterlibatan penuh para aktor lokal dalam perumusan kerangka kebijakan nasional.Dalam teori negosiasi identitas, atau menghadapi teori negotasi, Stella Ting Toomey (2008: 
159) memberikan cara-cara di mana identitas dinegosiasi dalam interaksi dengan orang, terutama dalam berbagai budaya. Stella Ting dan Toomey memfokuskan pada identitas etnik dan budaya, terutama perundingan yang berlangsung kompilasi kita berkomunikasi dalam dan di antara kelompok-kelompok masyarakat.

\section{Pemahaman Ethnic Identity dalam mengembangkan Toleransi Masyarakat}

Melalui Pendidikan dapat meningkatkan pemahaman identitas etnik dan mengembangakan toleransi di masyarakat.Dapat dikatakan pendidikan yang dilaksanakan dikota Metro dan pembinaan pemerintah Kota Metro relevan dengan prinsip-prinsip pendidikan multicultural. Tiga landasan dasar dalam teori negosiasi identitas yaitu:

a. Pengetahuan (knowledge) yaitu persepsi akan pentingnya identitas etnik dan kemampuan melihat apa yang penting bagi orang lain tentang budaya serta mampu melihat segala sesuatu perbedaan.

b. Kesadaran (perhatian) adalah secara sederhana sehari dan teliti untuk menyadari. Hal ini berarti kesiapan berganti ke perspektif baru.

c. Kemampuan (skill) yaitu kemampuan untuk menegoisasi identitas menonton teliti, menyimak, empati, kepekaan non verbal, kesopanan dan kolaborasi.

Merujuk pada 3 (tiga) pilar pendidikan nasional bahwa pendidikan berasal dari keluarga, sekolah dan masyarakat, maka dalam mengembangkan pemahaman ethnic identity dapat dilakukan pada tiga lembaga tersebut. Pemahaman identitas etnik dimulai dari pendidikan keluarga, diperdalam di lembaga pendidikan selanjutnya dapat dilaksanakan dalam kehidupan bermasyarakat. Pemberlakuan desentralisasi pendidikan dapat dijadikan oleh para pengembang pendidikan dan pemangku kepentingan untuk menjadikan pemahaman identitas sebagai bagian dari pembangunan bidang pendidikan. 
Mengamati realitas dinamika masyarakat kota Metro serta belum adanya konflik besar yang termuat dalam media atau menjadi berita nasional dapat dikatakan bahwa harmonisasi dan toleransi warga masyarakat selalu terjaga. Konflik yang diakibatkan oleh etnik, agama dan suku tidak pernah terjadi di Kota Metro Lampung. Seluruh sekolah di kota Metro wajib mengajarkan bahasa dan aksara lampung. Selain itu budaya dan tradisi lampung menjadi salah satu muatan dalam kegiatan ekstrakurikuler di sekolah. Untuk pemilihan Bujang dan Gadis Lampung di kota Metro, semua remaja dari etnis apa saja dipersilahkan dan diberikan kesempatan yang sama untuk berpartisipasi tidak harus keturunan suku Lampung. Penyertaan komponen budaya setiap suku sebagai bukti harmonisasi masyarakat di kota Metro terliha tjelas pada peringatan Hari Jadi Kota Metro setiap tahunnya diselenggarakan festival budaya yang melibatkan semua suku yang ada di Kota Metro Lampung.

Berbagai peristiwa konflik yang melanda di beberapa kabupaten di Provinsi Lampung bahkan sempat menjadi berita nasional, seperti Kasus Mesuji di Kabupaten Mesuji dan peristiwa terakhir kasus di Desa Balinuraga di Kabupaten Lampung Selatan dapat menjadi pelajaran berharga betapa pentingnya pemahaman Identitas Etnis sehingga dapat mengembangkan sikap toleransi dalam masyarakat. Kerjasama yang baik antar elemen suku, adat dan agama baik formal maupun non formal sangat dibutuhkan agar kejadian tersebut tidak terulang kembali dimanapun di wilayah Lampung dan khususnya di Kota Metro. Kerja sama yang baik antar pemerintah dengan masyarakat dan didukung oleh lembaga pendidikan dalam mengembangkan pemahaman identitas etnis dapat mengurangi terjadinya konflik yang disebabkan oleh gesekan etnis (suku).

\section{SIMPULAN}

a. Kota Metro Lampung sebagai kota terbesar kedua di Provinsi Lampung mempunyai keanekaragaman suku yang sangat banyak. Keberagaman masyarakat kota Metro terjadi akibat program Kolonisasi pada masa penjajahan dan program Transmigrasi pada masa setelah Kemerdekaan Republik Indonesia. Oleh karena pesatnya pembangunan dan kemajuan 
kota Metro banyak warga pendatang yang kemudian menetap dan tinggal menjadi warga kota Metro.

b. Secara umum keragaman suku, agama dan adat di kota Metro pada dasarnya sama dengan keragaman penduduk di kabupaten lainnya di Provinsi Lampung. Akan tetapi di Kota Metro tidak pernah terjadi konflik yang melibatkan suku dan agama. Kondisi kota metro sangat nyaman dan toleran. Stabilitas keamanan sangat terjaga sehingga proses pembangunan dapat terlaksana dengan baik.

c. Pemahaman Identitas etnis dapat dilakukan melalui jalur pendidikan, baik disekolah, keluarga dan masyarakat. Berdasarkan pengamatan seluruh sekolah di kota Metro wajib mengajarkan huruf (aksara) dan bahasa Lampung di semua tingkatan. Setiap suku dan adat yang berada di kota Metro diberikan ruang berekspresi dan diberikan kesempatan yang sama untuk tampil dan meeriahkan Hari Jadi Kota Metro setiap tahunnya. Pemilihan bujang gadis (muli' meng'anai) Lampung menyertakan seluruh pemuda pemudi Metro tidak terbatas untuk suku Lampung saja.

\section{DAFTAR PUSTAKA}

Andrew, R.M. 1997. Tolerance, Toleration, and the Liberal Tradition. Polity, 29(4), 593-623.

Akhsan Na'im, Hendry Syaputra, dkk. Hasil Sensus Penduduk 2010: Kewarganegaraan, Suku Bangsa, Agama, dan Bahasa Sehari-hari Penduduk Indonesia. Badan Pusat Statistik: Jakarta.

Bank Dunia. 2010. Pola-pola baru kekerasan di Indonesia: data awal dari enam provinsi dengan pengalaman konflik berskala tinggi. Policy Brief. Edisi III. November 2010.

Durante, C. 2012. Religious Liberty in a Multicultural Society. Journal of Church and State, 54 (3) Research Library

Bloome, D. (2017). Childhood family structure and intergenerational income mobility in the United States. Demography, 54(2), 541-569.

Istiningsih, S.S. 2016. The New Paradigm of Tolerance-Character Building Based On Multiculturalism through Religion Education. IOSR Journal of Research \& Method in Education (IOSR-JRME), 6(6), 38-45. 
Banks, J. A. (1993). Chapter 1: Multicultural education: Historical development, dimensions, and practice. Review of research in education, 19(1), 3-49.

Lexy J. Moelong, 2009. Metodologi Penelitian Kualitatif, Remaja Rosda Karya: Bandung.

Kementerian Agama Provinsi Lampung. 2016. Data Keagamaan Provinsi Lampung Tahun 2016.

Marcia, J. E. (1980). Identity in adolescence. Handbook of adolescent psychology, 9(11), 159-187.

Khamdan, M. (2015). Rethinking Deradikalisasi: Konstruksi Bina Damai Penanganan Terorisme. Addin, 9(1).

Mifdal Zusron Alfaqi. Memahami Indonesia melalui prespektif Nasionalisme, politik Identitas serta Solidaritas. Jurusan Pertahanan Nasional, Universitas Gadjah Mada Jl. Bulak Sumur email:mifdal.um@gmail.com

Pemerintah Kota Metro. 2013. Buku Putih Kota Metro Provinsi Lampung tahun 2013.

Syafei, H. tt. Peristiwa Balinuraga Lampung Selatan. Diakses dari https://lampung.kemenag.go.id/files/lampung/file/file/ARTIKEL/balinuraga.p df

Sri Astuti Buchari. 2014. Kebangkitan Etnis Menuju Politik Identitas. Yayasan Pustaka Obor. Jakarta.

Phinney, J. S., \& Chavira, V. (1992). Ethnic identity and self-esteem: An exploratory longitudinal study. Journal of adolescence, 15(3), 271-281.

Phinney, J. S. (1989). Stages of ethnic identity development in minority group adolescents. The Journal of Early Adolescence, 9(1-2), 34-49.

Suharsimi Arikunto. 2002. Prosedur Penelitian suatu Pendekatan Praktek. Reneka Cipta: Jakarta.

Smith, S. D. (1990). The Restoration of Tolerance. Calif. L. Rev., 78, 305.

Wakefield, W. D., \& Hudley, C. (2007). Ethnic and racial identity and adolescent well-being. Theory into Practice, 46(2), 147-154.

(http://www.teraslampung.com/2014/02/sejarah-kolonisas-dilampungimereka.html diakses pada tanggal 4 April 2014). 